\title{
The Kenya Land Commission and the Mwea Land Question, 1932 - 1934
}

\author{
Gichobi Thomas Njiru ${ }^{1}$ and Peter Wagura waweru ${ }^{2}$ \\ ${ }^{\prime}$ Master's student of History, Department of Public Affairs and Environmental Studies at Laikipia University \\ P.O Box 799-10300 Kerugoya, Kenya \\ ${ }^{2}$ Senior Lecturer of History, Department of Public Affairs and Environmental Studies at Laikipia University, $1100-20300$ \\ Nyahururu Kenya
}

\begin{abstract}
Several years after independence land related conflicts still hovers in Mwea area. Despite the creation of a National Land Commission to handle land issues by Kenya's 2010 constitution, the issue of land use and ownership remains a major cause of conflict between communities notably the Agikyu, Aembu,Mbeere and Akamba. The roots of these conflicts dates back to colonial times. After alienating African land, the colonial state embarked on creating reserves to accommodate African communities. However, the so called African reserves were haphazardly established without consideration to such factors like fertility and future rise in population. Consequently, by 1920s the reserves were overcrowded, terribly denuded and could hardly support African productive capacities resulting to agitation for more land by African ethnicities. Surprisingly, up to 1930, the government of the day did little if any to redress land problems afflicting African population. In 1932, however, the colonial administration constituted the Kenya Land Commission (hereinafter KLC) to look into the land question and suggest a lasting solution to land grievances in the colony. The recommendations of KLC impacted heavily on land use and ownership in Kenya.
\end{abstract}

This paper therefore, examines the implications of the Kenya Land Commission on the Mwea land question.

Key Words: Land, Land Use, Mwea, Ownership, Reserve

\section{INTRODUCTION}

$\mathrm{I}_{\mathrm{n}}^{\mathrm{n}}$ 1895 Kenya was declared British Protectorate amidst protest by local African communities. This declaration marked the beginning of African struggle to retain ownership and utilization of what they termed as ancestral land. Colonial establishment in Kenya was characterized by massive expropriation of fertile African land to create room for European settlers. Having put in place a costly railway line from what is now Kenyan Coast to Uganda, the colonial government had to tactfully device ways of mitigating the cost of railway and fledgeling protectorate by making use of vast land in their newly acquired enclave. From 1901, White settlers started arriving in the colony following encouragement second Commissioner of the protectorate, Sir Charles Eliot, who believed in their ability to engage in large scale commercial farming as opposed to an African populace that was still struggling with a hoe to produce enough for subsistence. ${ }^{1}$

In earnest, the colonial government embarked on creating room for the settler class by alienating African land. Anderson observes that from the time when first European settlers arrived in 1902, land in the colony was divided according to races as it was in South Africa with European Areas; the famous "White Highlands" swallowing huge chunks of fertile African land. Furedi captures the state of affairs in the colony by pointing out that the major prize given to European settlers in Kenya was the White Highlands. The latter covered approximately $71 / 2$ million acres (3 million hectares) compared to about 33 million acres reserved for Africans. The land reserved for Europeans had the richest soil Kenya;-the area most suitable for commercial farming. ${ }^{2}$

The White Highlands were cleared of African occupation by forcefully evicting Africans from their ancestral land. Consequently, through the Colonial Land Ordinance of 1926 the famous African reserves were established to accommodate African ethnicities. Among the Agikuyu, three reserves were created; Kiambu (Kabete), Fort Hall (Murang'a) and South Nyeri (Gaki) reserves were established to accommodate the community whose land had since been alienated for White settlers. Other reserves in the colony included Laikipia for the Maasai, Meru, and Embu among others. ${ }^{3}$

Even after establishment African reserves, Mwea Plains continued to be a Frontier area because it lay at the border of different African reserves namely; Nyeri, Murang'a, Mbeere and Embu Reserves. Consequently, disputes over land utilization and ownership in the Mwea Plains persisted during the colonial and post-colonial period. ${ }^{4}$

The so called African reserves were established without consideration of such factors as population increase and fertility. Consequently by the end of the 1920s most of the African reserves were overcrowded, seriously eroded and

\footnotetext{
${ }^{1}$ David Anderson, Histories of the Hanged: Britain's Dirty War in Kenya and the End of the Empire (London,2005), p.3

${ }^{2}$ Frank Furedi, The Mau Mau War in Perspective (Nairobi,1989), p. 5

${ }^{3}$ Godfrey Muriuki, A History of the Kikuyu 1500-1900 (New York,1974), p 29

${ }^{4}$ R. Chambers and J. Morris, Mwea: An Irrigated Rice Settlement Scheme, (Muchen, 1973), 37-39.
} 
could hardly support African productive capacities. ${ }^{5}$ As combined problems of population pressure, land hunger and declining agricultural production continued to afflict Africans, clamour for more land by African leaders and chiefs set in. This clamour was characterized by formation of political organizations such as Young Kikuyu Association (YKA), Kikuyu Central Association (KCA), and UKamba Members Association (UMA) among others. Demands of alienated land led to rise of protests over what Africans termed oppressive colonial land policies ${ }^{6}$

In a bid to examine the land problem in the colony, the colonial government established the famous Kenya Land Commission (hereinafter KLC) in 1932. The KLC that is invariably known by its chairperson as Carter Commission was tasked to look into the land question in the colony and propose a lasting solution to land problems in Kenya. This land commission collected views between 1932 and 1933 and submitted its report to the colonial government in 1934. The land commission brushed and rejected a majority of African claims to land safe for the Samburu who successfully convinced it their historical ownership of Lorroki plateau. ${ }^{7}$ However, this commission ruled out additional land to the Africans and recommended redistribution of African population to ease congestion in overcrowded areas and conservation of other areas of the Reserves to improve production. Members of the land commission also recommended a number of reforms on African land tenure. In Mwea, community leaders and colonial administrator appeared in person or sent memorandum with their evidence with regard to land use and ownership in Mwea.

\subsection{The Evidence Adduced Before KLC on Mwea Land Use and Ownership}

Colonial land policies were enacted with interests of the settlers at the heart of their designers. Consequently, the colonial land ordinances trampled on African rights to access and own what they considered ancestral land. These legal writs were part of Whiteman's stratagem to reduce African folks to labourers on the settler estates. From October 1932 the stage was set for colonial administrators as well as leaders of the antagonistic communities; Aembu, Mbeere, Ndia and Gichugu to appear before the land commission at Nyeri to avail evidence regarding their stand on land use and ownership in Mwea. Kombo Wa Munyiri, colonial chief and leader of the Mbeere community was the first to take the stage before the commission. The leader asserted that traditionally, the Mbere used to gather honey and graze their livestock in Mwea. In fact, chief Kombo attempted to persuade the members of the land commission that Mbeere grazing pursuits spanned all the way to Mbonjuki where there were salt licks

\footnotetext{
${ }^{5}$ Anderson, 'Histories of the Hanged', pp 21-22

6 B. A Ogot and W.R, Ochieng, Decolonization and Independence in Kenya 1940-1963, (Nairobi, 1995), pp. 35-36.

${ }^{7}$ For detailed exposition on KLC and the Samburu land question see Peter Waweru, "Continuity and Change in Samburu Pastoralism Under Colonial Rule, C. 1909-1963”, Ph. Dh Thesis, Egerton University, 2006. Pp 111- 135
}

which were very important to their animals. According to him therefore, the Mwea enclave belonged to the Mbeere unequivocally.

When chief Kombo was put to task to explain how other communities ended up occupying what he termed the Mbeere land he retorted that, "Ndia only extended their claims over lower Mwea after the we [Mbeere] were forced to vacate the plain following raids by the Ukavi [Maasai] ${ }^{8}$. However, Kombo acknowledged that dispute with the Ndia over land use and ownership in Mwea were common and were always resolved through negotiations between elders from Mbeere and the Ndia people.

The Mbeere claims of ownership over Mwea Plain received support from Mr. H. E. Lambert, then District Commissioner of Embu. Lambert who had been the Embu District Commissioner since March 1929, acknowledged the Mbeere claims over Mwea by affirming that:

...their land extended a good deal west of this boundary (referring to Mbonjuki where the Northcote line passed). The Mbere in Mwea area were mainly pastoralists. A succession of Maasai raids deprived them great part of their stock and forced them to retire to their present country east of the Rupingazi and Thiba rivers. In or about 1919 the Ndia had taken to grazing their stock in the country claimed by the Mbere and friction between the tribes appeared likely. This was prevented by a meeting between the Githaka owners, chiefs and elders, at which the boundary was agreed upon and the usual oath of agreement was taken by the parties concerned. The original Mbere land extended into the area now considered Ndia. ${ }^{9}$

However, Mr Lambert acknowledged that it was difficult to locate the original boundary between the Ndia and the Mbeere territory. This clearly shows the frontier nature of Mwea Plain and how the porosity of territorial boundaries contributed to land dispute in Precolonial Mwea. In further support of the Mbeere claims, Lambert invoked the social - cultural significance of Mwea to the Mbeere community. He pointed out that there was no doubt that part of Mwea belonged to the Mbeere because there was a sacred groove, or rather a sacred tree, at Mbonjuki which was considered a tribal groove and which had been recently visited by elders of the Mbeere and Embu tribes as part of the succession of ceremonies connected with the Ndwiko, a ceremony to mark the transfer of power from one generation to the next.

\footnotetext{
${ }^{8}$ Chief Kombo Munyiri of the Embu Division Evidence Presented to Kenya Land Commission at Nyeri, $28^{\text {th }}$ October, 1932 Evidence, Vol. 1 p. 89

9 Mr. H. E. Lambert, Evidence Presented to the Kenya Land Commission, $3^{\text {rd }}$ November 1932, Evidence, Vol 1, pp. 553
} 
When it was the turn of the Ndia to prove to the KLC that Mwea belonged to them and not any other group, Chief Njega wa Gioko who claimed to have been speaking for about ten mbari from both the Ndia and Gichugu pointed that the Mbeere were not the owner of Mwea and his people had never entered in any agreement at around 1919 as alleged by Mbeere leaders and, the Embu District Commissioner, Mr. Lambert. He also refuted claims that the Ndia went to Mwea after the Mbeere were forced out by Maasai raids. In his presentation, Njega insisted that among the Ndia and the Gichugu, land was owned communally where clans occupied ridges that ran across the Ndia territory from Mount Kenya. In his evidence, Chief Njega affirmed:

The Mbeere are lying. There was no arrangement about the boundary. Mwea belongs to the Ndia, and it has belonged to them for very many years. Our fathers were there when they were boys and our grand fathers were born in Mwea. Mwea has belonged to us since the time of great-greatgreat-great grandfathers. I do not know there was a fight between the Mbere and the Maasai. I have never heard of such as a fight. The only fight between us and the Maaasi was about the time of eclipse (1896). The Ndia were first beaten, but then we joined in the Maasai and raided the Mbeere. There are about ten ridges running through Ndia from the mountain and these are occupied by the Ndia people down as low as Mwea. The mbere have not crossed the Kii and the Rupingazi rivers for a long time. Whenever they crossed we fought them. Our original boundary is the Rupingazi River till it joins the Thiba River, then the Thiba River till it joins the Thagana River. The land is held by clans not individuals. We showed Mr Lydekker the boundaries between clans we did not buy Mwea from the Wadorobo it has been our land for a very long time. The Europeans who built Fort Hall called in the Ndia Chiefs. I went with Mr. Northcote, who wanted me to show him where the railway could be built. There was peace when the European came, because the Government put a stop to fighting. Mbere put their beehives in Mwea and the Ndia, when grazing their cattle used to throw stones at hives and knock them down. An old man called Kugariura and his son, Gikutha, came to meet me and said they been sent by the Mbere to get me stop the smashing of beehives. I told them to bring the owners. We and the old man Kugariura, his son, and a man called Mwige, took oath to stop the smashing of beehives. The oat was also directed against witchcraft. If the Mbere saythe boundary is the Main road from Fort Hall they are lying. Could I alone have given land to the Mbere? Kombo, Rumbia and Mathiga were Chiefs at the time. Why did they themselves not come to the meeting at which the alleged agreement was made, and why was no report made to the District Commissioner? ${ }^{10}$

The story by Njega was full of inconsistencies. Initially he claimed that the Ndia had never had an agreement to do with land use in Mwea but later acknowledged having met some people from the Mbeere community where they took an oath allegedly to stop smashing of beehives. However, Njega's evidence brings forth two important things; that the Mbeere were making use of Mwea Pain and that disagreement over ownership of Mwea existed between the two communities.

Other colonial administrators who were called to give their views about the various African groups' claim over Mwea openly called upon the colonial authorities to allow different communities to continue utilizing Mwea for various economic activities like grazing while at the same time recommended expansion of cultivation activities in the Mwea Plain which they considered to have been underutilised. One such proponent of these ideas was J. W. Pease, District Commissioner for South Nyeri, who pointed to the land commissioners that the area in Mwea that had been in dispute between the Ndia and the Mbeere had been in several districts. First in Fort Hall, about 1912, when the Northcote line was drawn, then partly in Nyeri, partly in Embu, then entirely in Nyeri after the transfer of Gichugu Division in 1922. ${ }^{11}$

To Mr. Pease, an absurd position was going to arise if change of administrative boundaries was to affect African rights to land for grazing, cultivation or residence since in some areas reserve boundaries like the case of the Fort Hall Reserve, boundaries in some places ran through the middle of clan and family Ithaka. With regard to land use and ownership over Mwea, when Pease was questioned about Embu - Nyeri boundary and who were the real owners of Mwea and how the land could be put into best use, he asserted:

I see no reason for changing the district boundary between Embu and Nyeri, and regards to 205 miles of Mwea should be included in the South Nyeri Reserve.... I do not think there is a doubt that the Ndia and Gichugu natives have most claims in this area according to law. The question was raised in 1912, 1914, 1925, 1926-1929, and it was always the South Nyeri natives who

\footnotetext{
${ }^{10}$ Chief Njega Wa Gioko of Ndia, Evidence presented to the Kenya Land Commission of 1932-1934, at Nyeri on $31^{\text {st }}$ Oct 1932, Evidence Vol II. P.252

${ }^{11}$ Mr. J.W. Pease, District commissioner for South Nyeri, Evidence Presented Before Land Commission on 3rd October, 1933, Evidence Vol. 1 pp529-530
} 
maintained claims to it. But I see nothing to stop Fort Hall and Mbere natives exercising any rights they have in native law of grazing and cultivation. A combined tribunal could deal with any dispute. I would not favour declaring the area compulsorily a grazing commonage. It will remain a grazing area for a good many years anyway, but I think the sooner cultivation spreads there and a system of mixed farming extends over the whole district the better. ${ }^{12}$

Apart from this, Pease made another suggestion that to date has served as a catalyst to land conflicts between the Ndia and Gichugu sections of the Agikuyu on one hand and the Aembu and Mbeere on the other. This was when he suggested that the three Kikuyu reserves; Kiambu Reserve, Fort Hall Reserve and Nyeri Reserve, what in colonial terms formed the Kikuyu Province, be gazetted as one whole reserve reserved for the Kikuyu and "kindred tribes" as Mr, Fazan, the District Commissioner for Fort Hall had already suggested. By so doing and after Mwea was added to the Kikuyu Reserve, the Kikuyu from overcrowded areas such as Kiambu could easily be settled in Mwea which now belonged to all Kikuyu.

Despite the differences that African leaders portrayed before the KLC over the ownership of land, the leaders seem to have reached a common ground regarding the retention of Mwea for use by Africans as hunting and grazing fields. Leaders like chief Njega of Ndia, chief Muruatetu of Embu, chief Nduini among others called upon government to allow their people to access Mwea for important resources like salt licks. ${ }^{13}$ In addition, community leaders unanimously complained to the government about the Northcote line that was drawn around 1912 saying it had limited the expansion of their parcels of land and their ability to utilize the forest and other resources like salt licks that had since been cut off from the land they owned as the government adopted the forest conservation policy by adopting this line to prevent further encroachment of Africans into the forest. Leaders like chief Muruatetu of Embu were vehement on this:

We have been told that if we have forest we will burn it. Before the Europeans came we did not burn it. We used to put our honey barrels there. We ask for the salt licks and also for that portion of the forest which was individually owned by natives according to native custom before the forest boundary was demarcated. We want the forest for timber for building our houses. There are many of the original owners who want to cultivate in forest where they used to cultivate, and we want to be able use small poles from this portion of the forest for house building. ${ }^{14}$

On his part, Chief Njega narrated how the colonial chief used colonial administrators to evict people from the Mount Kenya forest where they lived and cultivated the forest land once the Line was drawn when he pointed that:
After this boundary was marked out we could not get into the forest and we had our important trees there and we cannot go inside there again and get sufficient wood. As I was the chief, Government came and told me that I should go into the forest and turn out all the people who were living there and burn down their huts, which I did. The huts were uncountable, very, very many. Even now the huts of the people who lived there before the government came to this country. The huts were on land belonging to various githakas ${ }^{15}$

The Ndia, Gichugu and Aembu claims that they were already living and cultivating in the Mount Kenya forest without causing harm to it, long before the coming of Europeans and the drawing of the Northcote line to demarcate the forest reserve from their land, received support from Mr. H. E. Lambert when he was questioned as to whether there was need to make adjustment to the Forest Line and affirmed before Carter and his team that:

The main point is that the land inside the forest is just as much owned on the githaka system as the land outside it. The boundary when was demarcated, cut through the land which was held on githaka system so that a certain portion of it was taken away. It was mixed land. They cultivated in the glades and lived in the forest. They had definite rules amongst themselves. They did not burn the forest...there were instances of various fires but tribal elders imposed fines on people if they destroyed the forest at all. $^{16}$

The Africans plea to the land commission to recognize their land tenure, that allowed retention of common grazing fields, came under sharp criticism from Mr. S. H. Fazan, District Commissioner for Fort Hall (Murang'a) who earlier on while appearing before the Native Land Tenure Committee in Kikuyu Province of 1929 condemned the Githaka System. He called for the attention of government to remember that the Kikuyu Reserve had been reserved for all Kikuyu people and there was therefore no need to hold back any land from

\footnotetext{
14 Chief Muruatetu, Memorandum presented to the KLC, 1932-1934, Evidence vol. 1 pp. $89-90$

${ }^{15}$ Chief Njega Wa Gioko, Oral evidence before KLC, Evidence Vol. 1, p. 258

${ }^{16} \mathrm{Mr} \mathrm{H}$. E. Lambert, Evidence Presented to the Kenya Land Commission, $28^{\text {th }}$ January, 1933, Evidence, Vol 1, pp. 551
}

${ }^{12}$ Ibid, pp. 529

${ }^{13}$ Ibid, p. 534 
cultivation in the name of preserving pasture land for some Kikuyu stock:

...we must remember that the Kikuyu Reserve is reserved for the Kikuyu as a whole and not for thee special benefit of those fortunate families whose ancestors hunted over the widest stretches of forest...The additional danger that large areas may be withheld from cultivation for the sake of pasturing uneconomic goats is by no means fanciful...There is an area of 205 square miles in Mwea which is uninhabited by any permanent population except the occupants of about sixty huts. Over large part of this Ithaka are pretended. It seems to me to be self-evident that a general recognition cannot be accorded the Ithaka system without the most adequate safeguards ${ }^{17}$.

Fazan's views were accepted by the Kenya Land Commission and they influenced the opening of Mwea for use by all Kikuyu people not only the Ndia and Gichugu.

\section{FINDINGS AND RECOMMENDATIONS OF KLC ON MWEA}

The findings and recommendations of the KLC on the Mwea land question were based on an investigation that largely ignored most aspects of the traditional African land tenure for instance, the Githaka System that existed among the Agikuyu. The recommendations of this land commission therefore, only served to exacerbate other land use and ownership grievances in Mwea. In addition, KLC recommendations nurtured seeds of antagonism between African communities in Mwea in addition to growing African nationalism that would later be expressed violently through the outbreak of the Mau Mau rebellion in the 1950s. Without a doubt, the following recommendations by the land commission had resounding effects and influence on land use and ownership in Mwea.

\subsection{Mwea as an Answer to Overcrowding in Kikuyu Reserves}

Some Africans communities especially the Kikuyus in the reserves of Kiambu, Fort Hall (Murang'a) and South Nyeri had for a long time complained to the government of the rising population and overcrowding in their reserves. Indeed, they hoped to find recourse in the KLC enquiry. The KLC established that most of the African areas were experiencing a threatening rise in population and overcrowding in some areas. This overcrowding, according to the land commission was to continue afflicting the reserves if nothing was done in the shortest time possible to redistribute the African population whose numbers were constantly on the rise. In fact, the evidence adduced by Carter and his team pointed to a high rate in increase of the African population, and the

\footnotetext{
${ }^{17}$ Colony and Protectorate of Kenya, Native Land Tenure in Kikuyu Province
} (The Maxwell Report), (Nairobi ,1929), p. 39 members of the commission, "could not discern any slackening of the rate population growth rate among these ethnic groups at least for decades ahead as a result of improved medical and nutritional conditions'. ${ }^{18}$

According to the findings of KLC, the overcrowding that African reserves were experiencing was however, as a result of African inability to evenly distribute themselves across their land in the reserve thus making certain parts of their reserves to choke with numbers while other parts lay sparsely populated. The government intervention was therefore urgently needed to solve overcrowding in African areas especially among the Kikuyu. This was to be done through population redistribution in African areas. That is, moving some Africans from overcrowded areas like Kiambu and then resettling them in sparsely populated or those areas that were perceived, at least by the colonial state, to have been vacant and devoid of any human settlement such as the Mwea Plain.

Paradoxically, whereas the Kikuyu reserves, especially Kiambu, were suffering from overcrowding due to what the land commission termed as "mal-distribution of the African population" some African reserves like Maasai Reserve were sparsely populated. With the existence of these sparsely populated areas, the quickest solution to population pressure in the Kikuyu reserves could have been resettling some of the Kikuyu population in the neighbouring Maasai reserve. However, the commission warned the government against such a move because it was likely to elicit resistance from the Maasai. As a result, the overpopulation and overcrowding in Kiambu Reserve could only be addressed by moving a section of Kikuyu population from Kiambu to other areas that were classified as Kikuyu areas and that were said to sparsely populated or at least vacant land that could accommodate fellow landless Kikuyu.

It was also found that squatters who were returning from the Scheduled Areas (White Highlands) were contributing to overcrowding of African reserves. More specifically the commission found that, at the time, a squatter population of about 150,000 persons, or 30,000 families, two thirds of which were Kikuyu, existed outside the reserve and in the event they returned, which they eventually did, land problem in the Kikuyu reserves was going to rise to dangerous levels. According to the views of the commission, African reserves were in a position to accommodate natural rise of their population but any rise in squatter population could not be accommodated in the reserves without bringing the government 'very grave embarrassment'. ${ }^{19}$

Having been influenced by the European settlers, the land commission argued, the returning Kikuyu and other African squatters would have preferred to return to their reserves rather than take up land on some form of private tenure in an alternative area, even if it was made available for them. However, the more they could do this, the greater the strain

\footnotetext{
${ }^{18}$ Kenya Land Commission, 1932-1934, Vol.3, Report, p. 350

${ }^{19}$ Kenya Land Commission, p. 378
} 
they could cause on the reserves that were already densely populated. It was also noted that in the near future the reserves were going to fill up and it was going to be increasingly difficult for 'natives', who had been long absent, to return and cultivate or find room for their stock in the reserves. The increased individualism and independence of mind which the squatters would have acquired in the settled areas was going to incline them to seek places where they could hold land on private title, if such areas could be found.

\subsection{Changing of African Land Tenure in Mwea}

Land tenure in Mwea, like most areas inhabited by Africans was communal though individual persons had certain rights with regard to cultivation parcels. ${ }^{20}$ According Carter and his team the Githaka system of land tenure as practiced by the Kikuyu was lacking in many aspects. For instance, Ahoi or landless tenants could be evicted at will without compensation by the landed Githaka landlords. The members of the land commission therefore recommended replacement of communal ownership of land with individual land tenure. Under the new land tenure people would be guaranteed security of their land, a move that would encourage people to develop their land without fear of eviction.

The Carter led team also recommended regulation of the Githaka system of land ownership to curb fragmentation of land that was fast threatening to reduce land in African areas into uneconomical pieces if it continued unabated. It is important to note here that the solution to land fragmentation in the colony found cure in the Swynnerton Plan of 1954 that initiated land consolidation in Kenya. In Mwea, the exercise of consolidating fragmented African land parcels began around 1956 and continued in independent Kenya. ${ }^{21}$

The Githaka system as was practised by the Ndia, Gichugu and others in Mwea area came under sharp criticism. According to KLC, this system of land tenure tended to encourage land degradation as people engaged in uncontrolled grazing in common grazing fields such those of Mwea Plain. On this, the land commissioners concurred with Mr. Fazan who warned against preserving tribal grazing fields but rather recommended expansion of cultivation in those areas like Mwea Plain which had been reserved as common grazing fields. However, while the members of KLC took issue with African land tenure, it openly admitted that it had not done enough study over land use among the Kikuyu where common pasture lands existed:

While we have not ourselves had time to make a close study of the subject as would justify us in dealing with it in the body of our report, we wish to record our general agreement with the conclusions reached by Mr. Fazan....While we realize the difficulties of creating private rights in areas such as Ndeiya and Mwea, where none are at present recognized, yet we consider that large areas should not be used exclusively as grazing commonages, since they lead to large accumulation of stock far away from the homes of their owners, where they are useless as a source of milk supply; while, so long as grazing rights remain common, no attempt is made to spare the land or the pasture, which rapidly deteriorates. The private appearance of private rights similar to those obtaining in the rest of the reserve would be generally desirable if suitable method would be suitable. The common right of pasturage over Githaka land also leads to overstocking, since small regard is given to the carrying capacity of land. ${ }^{22}$

\subsection{Profit and Loss Account of KLC: Using Mwea to compensate Land Loss in Other Areas}

Among the many factors that led to African resistance in colonial Kenya, land alienation was without a doubt a major trigger of these resistance. It is by no surprise therefore that the colonial state instituted the Kenya Land Commission in 1932 specifically to look into land question in the colony and provide a lasting solution, to a problem that was a becoming a threat to colonial order. In the list KLC mandate was to investigate and recommend to government if Africans really need any additional land or not. With regard to Africans demand for more land, the land commission found that Africans had enough land and only recommended that their population be encouraged to adopt better farming methods so as to increase land productivity. The government, the commission advised, could come in and help setting up demonstration farms to educate Africans on better land use and farming practices.

On a positive note however, the commission found that in some African areas land had actually been alienated by government without due compensation to the affected people. On a sad note however, the commission recommended compensation of community land or what among the Agikuyu was regarded as Mbari land. Individual loss of land was only entertained where substantial evidence beyond doubt existed.

In compensating land lost in various reserves KLC adopted what it termed 'profit and loss account' where the land alienated by colonial government was tabulated against land that was considered legitimate territory of a given ethnic community plus land that was categorized as 'half given' given by government and 'half taken' by the community. Through these calculations, the land commission came to a conclusion as to whether a community had lost or gained land in the whole process. 'Legitimate territory' of a given 'tribe' was used to refer to land that was already occupied by an

\footnotetext{
${ }^{22}$ Kenya Land Commission 1932-1934, Report, p. 151
}

${ }^{20}$ Mwai Wamugunda, O.I, April 25, 2020
${ }^{21}$ Chambers, 1969, .62 
African ethnic community before the declaration of the protectorate in 1895. Land that was occupied or used by a community between 1895 and 1902 was regarded as 'half given' by government and 'half taken' by the community or in other words what the land commission referred to as "admissibly acquired land" land through clearing and use as was the norm in most African communities.

In the Kikuyu Reserve that now comprised of Kiambu, Fort Hall and Nyeri the land commission established that as whole the reserve had lost land through alienation by government amounting to 109.5 square miles. To compensate for this loss, the commission advised the colonial administration to add 174.4 square miles of Mwea to Nyeri District and another additional of 90.5 square miles of land to Kiambu District to the Kikuyu Reserve. The conclusion of this was that the Kikuyu Reserve after these additions had made a net gain of 156 square miles of land. The following table summarises the calculations that were made by the KLC with respect to the Kikuyu Reserve.

Table 1. Profit and Loss Calculations of Land for Kikuyu Districts

\begin{tabular}{|l|l|l|l|l|}
\hline District & $\begin{array}{l}\text { Land taken by } \\
\text { Government in } \\
\text { sq. Miles }\end{array}$ & $\begin{array}{l}\text { Land given by } \\
\text { Government in } \\
\text { sq. Miles }\end{array}$ & $\begin{array}{l}\text { Net gain } \\
\text { in sq. } \\
\text { miles }\end{array}$ & $\begin{array}{l}\text { Net loss } \\
\text { in sq. } \\
\text { Miles }\end{array}$ \\
\hline $\begin{array}{l}\text { Nyeri } \\
\text { District }\end{array}$ & 6.95 & 174.4 & 167.60 & 000 \\
\hline $\begin{array}{l}\text { Fort Hall } \\
\text { District }\end{array}$ & 9.14 & 000 & 000 & 9.14 \\
\hline $\begin{array}{l}\text { Kiambu } \\
\text { District }\end{array}$ & 93.41 & 90.95 & 000 & 2.46 \\
\hline Total & 109.50 & 265.50 & 167.60 & 11.60 \\
\hline Net gain & & & 156 & 000 \\
\hline
\end{tabular}

Source: Report of Kenya Land Commission 1932 - 1934, p. 74

As shown in the table above, the commission found that there was loss of land by the Kikuyu Reserve. It was against this backdrop that the land commission decided to allot Mwea Plain, 174.45 square miles as part of government's compensation to the Kikuyu for the land loss they had suffered. However, a problem arose when it was realized that the colonial government had established the three Kikuyu reserves of Kiambu, South Nyeri and Fort Hall as distinct reserves which meant moving kikuyu population from one of these reserve to another was bound to elicit resistance from the inhabitants of the reserves. To solve this problem, the KLC advised the colonial administration to gazette the three Kikuyu reserves as a single unit reserved for the entire Kikuyu community as Pease had suggested. ${ }^{23}$

But still the question regarding who were the rightful owners of Mwea, whether the Aembu, Mbeere, Ndia and Gichugu remained unanswered. As noted earlier, Mwea Plain was a frontier area for different reserves. Notably Embu, Kamba, Fort Hall and Nyeri reserves. African groups in these colonial enclaves had some historical rights to the Mwea Plain as members of the KLC acknowledged. Indeed, the Aembu and

${ }^{23}$ Kenya Land Commission,1932-1934, Vol. III, Report P.368
Mbere territory extended up River Nyamindi down to the plain before the boundary was shifted in 1922 when Gichugu Division was moved from Embu to South Nyeri District. As such the Embu reserve that was occupied by the Aembu and Mbeere people extended to Mwea Plain. However, the land commission advised the government to take advantage of the change of boundary back in 1922 to create an idea that Mwea Plain had always and entirely belonged to the Kikuyu people in the Kikuyu Reserve:

In order not to complicate the issue unnecessarily, it is therefore better to show the present boundary, the Rupingazi, as if it had always been the boundary between the Kikuyu and the Embu. This boundary begins at the point where the where the Kii River (which afterwards become Rupingazi River) emerges from Mount Kenya Forest Reserve and goes south by this river to the Thiba River. $^{24}$

The move by KLC to allot Mwea to the Kikuyu Reserve or to the Kikuyu people planted seed of land related conflicts that still persist in Mwea area between the Kikuyu, Aembu, and Mbeere communities. This is because other communities that had previously utilized the plain could no longer do so. In fact, following this recommendation the government moved to force out other communities especially the Kamba to return to their designated reserves. On the other hand, the move by KLC opened Mwea Plain for use by all Kikuyu not just the Ndia and Gichugu. In pre - colonial times the landless Kikuyu from Kiambu, Fort Hall and Nyeri could only settle in Mwea as Ahoi with permission from the Ndia and Gichugu elders. The status of Ahoi in Mwea was precarious as they could be evicted, sometimes without compensation, by their Ndia and Gichugu landlords. However, with KLC recommendation the landless people from other Kikuyu areas could be settled in Mwea with equal rights like the Ndia and Gichugu.

\subsection{KLC and the Genesis of Tenancy in Mwea}

The origin of tenancy in Mwea Irrigation and Settlement Scheme, which is discussed in detail in the next chapter, can be traced from the recommendations of the KLC. The land commission advised the colonial administration to ensure that any future land that was to be added on the native reserves had to be on leasehold or tenancy basis to enable the government maintain control over the occupants:

It is with the purpose of avoiding too much permanency that we shall recommend that extensions made to native reserves from time to time on economic grounds should not be permanently guaranteed but should be added by means of lease on terms that would provide an adequate security, subject

\footnotetext{
${ }^{24}$ Ibid, p. 67
} 
to reasonable conditions of use and development. $^{25}$

The issue of tenancy remains emotive in MISS. To date, inhabitants of the scheme have not been issued with individual title deed, a revered document in matters of land ownership in Kenya, as one Kiura wa Kibungo affirmed:

Without a title deed you cannot really say that you are the owner of this or that piece of land. Without the title deeds we feel insecure and as if we are not full Kenyans because it is very easy to wake up one day and you told to leave the land you occupy since we remain tenants of the state as it was during the colonial rule. In fact, for us, without title deeds to prove ownership of land nothing changed even colonial rule ended. $^{26}$

Further to this, the land commission recommended the division of land in African areas or what was referred to as in colonial phraseology as "native areas" into; native lands, temporary native reserves and native leasehold areas. The latter comprised all those areas like lower Mwea which were considered as "given by government" as compensation to loss of land by an African reserve, in this case Kikuyu Reserve. The colonial government enacted the Kenya (Native Areas) Order-in-Council of 1939 to effect this recommendation. The Native Lands Trust Boards were also formed to hold these lands in trust for African use. Lands that were categorised as native leasehold areas remained "Crown land" and Africans who settled in those areas like Lower Mwea (where MISS is located) were considered as tenants. This continued in independent Kenya where these lands were considered as government land hence no freehold title deeds were issued to the tenants.

Fast forward, successive government have done little to address long standing land issues in Mwea. More specifically, the issue of land ownership and titling of land in Mwea Irrigation and Settlement Scheme remains unresolved. Surprisingly, in its annual report 2015/2016 NLC affirmed to have resolved land related conflict in various parts of Kenya. ${ }^{27}$ Recent fracas in Makima areas of Mwea provide important lenses to view and analyse underlying land issues in the region. ${ }^{28}$

\section{CONCLUSION}

From the foregoing discussion, it is clear that the investigations of the Kenya Land Commission into Mwea land question did not solve African land grievances in the Mwea area. In fact, it's recommendations aggravated existing grievances and also created new land related problems in the area. At the face of KLC recommendations, for instance, tenancy system of land ownership was introduced in Mwea once MISS was set up. As tenants of the state, African farmers could easily lose their tenancy sometimes on flimsy counts. By opening up Mwea for all Kikuyu, KLC sounded a death knell to livestock rearing in Mwea as the common pasturage was to be used to settle people overcrowded areas of the Kikuyu Reserve.

In addition, the KLC recommendations led to increased strife between the Kikuyu and other communities notably the Akamba, Aembu and Mbeere over Mwea Plain which was solely allotted to the Kikuyu Reserve thus locking out other communities from utilizing land in the plain.

\section{REFERENCES}

[1] Antony Clayton, The Killing Fields of Kenya 1952-1960; British Military Operation Against Mau Mau(Nairobi,2006)

[2] Bethwel. A Ogot and W.R, Ochieng, Decolonization and Independence in Kenya 1940-1963, (Nairobi, 1995).

[3] Chambers. R. Settlement Schemes in Tropical Africa: A Study of Organization

[4] and Development, (London, Routledge and Keagan Paul1969).

[5] Chambers, R and Moris, J. Mwea, an Iirrigated Rice Settlement in Kenya, (Munchen: Weltforum Verlag, 1973).

[6] David Anderson, Histories of the Hanged: Britain's Dirty War in Kenya and the End of the Empire (London,2005) Frank Furedi, The Mau Mau War in Perspective (Nairobi,1989).

[7] Godfrey Muriuki, A History of the Kikuyu 1500-1900 (New York, 1974).

[8] Waweru, P. "Ecology Control and Development of Pastoralism among the Samburu of North- Central Kenya 1739-1909”, M.A Thesis of Kenyatta University, 1993.

[9] Waweru, P. "Continuity and Change in Samburu Pastoralism Under Colonial Rule, C. 1909-1963”, Ph. Dh Thesis, Egerton University, 2006.

[10] Colony and Protectorate of Kenya, Native Land Tenure in Kikuyu Province (The Maxwell Report), (Nairobi ,1929).

[11] Kenya Land Commission 1932-1934, Evidence, Vol.1 and 2

[12] Kenya Land Commission 1932-1934, Vol. 3, Report

[13] Colony and Protectorate of Kenya, Native Land Tenure in Kikuyu Province (The Maxwell Report), (Nairobi ,1929)

[14] National Land Commission Report 2025/2016

[15] H. E. Lambert, Evidence Presented to the Kenya Land Commission, 28 ${ }^{\text {th }}$ January, 1933, Evidence, Vol 1

[16] Chief Muruatetu, Memorandum presented to the KLC, 1932-1934, Evidence vol. 1 pp. 89-90

[17] Chief Njega Wa Gioko, Oral evidence before KLC, Evidence Vol. 1, p. $258^{1}$ Mr. J.W. Pease, Evidence before Kenya Land Commission 1932-1934, Evidence, Vol. 1 pp. 529

[18] Kiura wa Kibungo, O.I, April 26, 2020

[19] Mwai Wamugunda, O. I, April 21, 2020

${ }^{25}$ Kenya Land Commission 1932-1934, Vol. 3, Report, p. 353

${ }^{26}$ Kiura wa Kibungo, O.I, April 26, 2020

${ }^{27}$ National Land Commission, Annual Report, 2015/2016, pp. 35-36.

${ }^{28}$ See for example the Standard Newspapers of $27^{\text {th }}$ May. 2019 